NBER WORKING PAPER SERIES

\title{
LEGAL-POLITICAL FACTORS AND THE HISTORICAL EVOLUTION OF THE FINANCE-GROWTH LINK
}

\author{
Michael D. Bordo \\ Peter L. Rousseau \\ Working Paper 12035 \\ http://www.nber.org/papers/w12035 \\ NATIONAL BUREAU OF ECONOMIC RESEARCH \\ 1050 Massachusetts Avenue \\ Cambridge, MA 02138 \\ February 2006
}

This paper was prepared for the first Economic History Panel: Past, Present, and Policy, sponsored by the CEPR, the Oesterreichische Nationalbank, and Sciences PO and held in Vienna, Austria on September 30October 1, 2005. The authors thank Marc Flandreau (the conference organizer), as well as Lee Alston, Naomi Lamoreaux, Gary Libecap, and participants at the meeting of the program on the Development of the American Economy held as part of the NBER's 2004 Summer Institute for comments and discussion on an earlier version of this work. The views expressed herein are those of the author(s) and do not necessarily reflect the views of the National Bureau of Economic Research.

(C2006 by Michael D. Bordo and Peter L. Rousseau. All rights reserved. Short sections of text, not to exceed two paragraphs, may be quoted without explicit permission provided that full credit, including (C) notice, is given to the source. 
Legal-Political Factors and the Historical Evolution of the Finance-Growth Link Michael D. Bordo and Peter L. Rousseau

NBER Working Paper No. 12035

February 2006

JEL No. E44, F3, N1, N2

\begin{abstract}
$\underline{\text { ABSTRACT }}$
Recent cross-country investigations of the role of institutional fundamentals such as the protection of property rights in promoting financial development have extended a literature that has for decades maintained that financial factors can affect real outcomes. In this paper we pursue this new direction by considering relationships between finance, growth, legal origin, and political environment in a historical cross-section of 17 countries covering the period from 1880 to 1997 . We find that relationships between a county's legal origin (i.e., English, French, German, or Scandinavian) and financial development are roughly consistent with earlier findings but are not persistent. At the same time, political variables such as proportional representation election systems, frequent elections, universal female suffrage, and infrequent revolutions or coups seem linked to larger financial sectors and higher conditional rates of economic growth. Despite the explanatory power of some of our measures of the deeper "fundamentals," however, a significant part of the growth-enhancing role of financial development remains unexplained by them.
\end{abstract}

\author{
Michael D. Bordo \\ Department of Economics \\ Harvard University \\ Littauer Center - Room M27 \\ Cambridge, MA 02138 \\ and NBER \\ bordo@economics.rutgers.edu \\ Peter L. Rousseau \\ Department of Economics \\ Vanderbilt University \\ Box 1819 Station B \\ Nashville, TN 37235 \\ and NBER \\ peter.l.rousseau@vanderbilt.edu
}




\section{Introduction}

A growing literature over the last decade finds strong and robust links between financial development and subsequent economic growth. Most of the evidence derives from cross-country studies of as many as 120 countries with data starting in 1960 or later (e.g., King and Levine 1993; Levine, Loayza, and Beck 2000; Rousseau and Wachtel 2000, among others). And while the evidence on the direction of causation is certainly not airtight, nor should we expect causation to be unidirectional in the long run, a number of supporting time series studies offer evidence that finance does not simply follow growth, but rather leads to it (Demetriades and Hussein 1996; Rousseau and Wachtel 1998).

A number of economic historians (Gerschenkron 1962; Cameron 1967; Sylla 1969) and development economists (Goldsmith 1969; McKinnon 1973) have long argued for a central role of the financial sector in promoting long-run growth but have traditionally studied the question with individual case studies or comparisons of small groups of countries. Only recently have Rousseau and Sylla (2003) and Rousseau (2003) applied the tools of modern macroeconomics to examine the link econometrically over longer periods of history. Though limited in scope by the available data for countries that would today for the most part be considered "developed" members of the "Atlantic" economy, these studies suggest that financial factors may have been even more important in promoting growth in the 17 th, 18 th and 19 th centuries than they are today.

One reason why we might expect financial factors to affect economic growth involves the deep endogeneity of financial development itself. By this we mean that the extent of finance in a given country may be linked to institutional preconditions established long before the start of modern economic growth. A newer literature suggests that the existence of institutions that aid in the protection of property rights may be among these preconditions (Acemoglu, Johnson, and Robinson 
2001). Further, such institutions may be even more deeply linked to the tradition from which a nation’s legal system emerged (La Porta et al., 1997, 1998; Beck and Levine 2002, 2004).

Though the more recent studies are appealing from a theoretical perspective, the problem of measuring the willingness and ability to enforce "property rights" is a serious one. Acemoglu et al. (2001) employ the mortality rate of European troops in various colonies as a measure of the mortality rates of actual settlers, and then argue that this is also a good proxy for the protection of property rights. Though this may at first glance seem to be a weak instrument, it actually performs very well in explaining a significant part of the variation in per capita incomes today. La Porta et al. (1997) use dummy variables to distinguish countries by their legal tradition (i.e., distinguishing the English common law tradition from French, German, or Scandinavian civil law traditions). These indicators explain a considerable amount of today's cross-country variation in financial development for a wide cross-section of developed and developing countries. With either approach, however, it is possible that the proxies used to reflect the deeper fundamental also capture the combined role of other factors not related to the protection of property rights.

In this paper, we take the historical analysis of Rousseau and Sylla (2003) as a starting point for exploring the importance of these deeper fundamentals in fostering financial development and economic growth. Among the fundamentals that we consider are legal origin as classified by La Porta et al. (1997) and characteristics of the political environment. We include the latter because more stable and democratic governments should provide more stable monetary arrangements and greater protection of property rights than less democratic or unstable ones. We then ask how much of long-run growth can be explained by the residual component of financial development (i.e., the part not related to predetermined legal-political factors).

Our priors come from the economic history story told by Sylla (2002) and the earlier 
literature. The Netherlands and England experienced financial revolutions in the 17th and 18th centuries. In the Netherlands a market for government bonds developed when the United Provinces secured an effective tax base (de Vries and van der Woude 1997). England adopted the Dutch innovations after the Glorious Revolution of 1688. Secure taxes led to the development of a market for long-term bonds and then the Bank of England to serve as the government's fiscal agent. The other aspects of financial development -- a banking system, stock market, money market and insurance industry - followed from these 18th-century origins (Capie 2001a, 2001b). In both cases, secure property rights protected by the legal system and some form of representational government were required before an effective tax regime could be established. These institutions ensured that those from whom taxes were levied had some say in both the nature and extent of taxation and its disbursement.

The case of the United States has been well documented. The 13 colonies inherited British and Dutch traditions of secure property rights and representational government. Alexander Hamilton created the American financial revolution with his stabilization package of 1790 that funded the government debt and instituted secure taxation to service it. With the financial revolution came a sinking fund and a bank of issue, the First Bank of the United States. Sylla (1998) and Rousseau and Sylla (2005) document the subsequent evolution of the stock market, commercial paper market, insurance and banking in the first few decades of the 19th century.

These examples and also those of France, Germany and Japan serve as the benchmarks for our empirical analysis.

Our focus on historical data and analysis is useful because if dummy variables for a country's legal origin truly reflect fundamental predetermined factors in financial development, we should expect their effects to persist. In other words, the role of, say, English legal origin in promoting 
financial development should not change qualitatively whether we examine a cross-section of countries from an earlier period of history (1880-1929) or a later one (1945-1994). Further, we should expect the basic relationships to be robust to working with a narrower group of nowdeveloped countries to provide consistency across more than a century of data. The general relationships between measures of the political environment on the one hand and financial and real outcomes on the other should also be consistent across time, though we may expect various political variables to become more or less important since political environments can and do evolve.

The rest of the paper is organized as follows. Section 2 considers the role of legal origin in promoting finance and growth, and section 3 investigates the role of political factors. We examine the legal and political factors jointly in section 4 . In section 5, we focus on the growth-enhancing component of financial development that remains unexplained by legal-political factors. Section 6 draws together some preliminary conclusions.

\section{Legal Origin, Finance, and Growth}

The "law and finance" literature (e.g., La Porta et al. 1997, 1998; Beck and Levine 2002, 2004) asserts that a country's legal origin is related to its willingness and ability to protect the property rights of individuals and to enforce private contracts, and that these factors in turn increase the propensity of potential investors to hold financial assets. Countries with better protection of property rights and private contracts should therefore be able to accumulate capital and achieve financial deepening more readily than countries with less secure property rights. In general, this literature also contends that the common law (i.e., English) tradition, with laws usually made by judges and later incorporated into legislation, provides for better protection of property rights than the civil law (i.e., French, German, and Scandinavian) tradition, where scholars and legislators are at 
the center of the lawmaking process and protection of the State tends to be favored over the protection of individuals.

Among the three civil law traditions, French law is considered to be the most rigidly codified and thus the least adaptable. It was formed during the Napoleonic era when judges were viewed with some degree of suspicion by the State, and unlike German civil law was therefore not as strongly rooted in centuries of court decisions. The Scandinavian civil law tradition is considered to be quite different than either the French or German traditions, and its flexibility is believed to lie somewhere between them. French civil law spread through continental Europe, Latin America and to a few African and Asian countries, while English civil law spread to Canada, the United States, and most Australasian and sub-Saharan African countries. German civil law spread to a handful of countries including Austria, Switzerland, Japan, Korea, and Taiwan. Scandinavian civil law did not spread beyond the Nordic countries.

If legal adaptability is related to the protection of investors and their property rights, then according to the "law and finance" view we should find countries with English legal origins having the largest financial sectors, followed respectively by countries with German, Scandinavian, and French civil law. La Porta et al (1997, Table II, p. 1138) find that this is indeed the case for financial development in 1994 when measured as the value of equity held by minority shareholders divided by gross domestic product (GDP) in a large sample of 49 developed and developing countries. Earlier studies have not considered an explicit link from legal origin to economic growth operating through the financial sector, but if financial development is a first-order determinant of economic growth after controlling for the level of income, we would expect in our analysis to find growth outcomes related to legal origin in a similar manner. 


\begin{tabular}{|c|c|c|c|c|c|c|c|c|c|}
\hline \multirow{3}{*}{ Australia } & \multicolumn{3}{|c|}{ Per Capita Income (1960 US\$) } & \multirow{2}{*}{\multicolumn{3}{|c|}{$\begin{array}{l}\text { \% Growth Real Per Capita Income } \\
1880-1997 \quad 1880-1929 \quad 1945-1997 \\
\end{array}$}} & \multicolumn{3}{|c|}{ Broad Money (\% of GDP) } \\
\hline & 1880 & 1929 & 1990 & & & & $1880-1997$ & $1880-1929$ & $1945-1997$ \\
\hline & 874 & 886 & 3,092 & 1.33 & 0.21 & 2.06 & 49.1 & 42.5 & 55.9 \\
\hline Canada & 447 & 1,266 & 3,727 & 2.00 & 2.14 & 1.58 & 43.2 & 35.6 & 51.4 \\
\hline United Kingdom & 660 & 697 & 2,623 & 1.38 & 0.21 & 2.41 & 50.5 & 54.4 & 42.1 \\
\hline United States & 604 & 1,277 & 5,017 & 2.04 & 1.46 & 1.66 & 61.6 & 52.5 & 66.3 \\
\hline English-origin average & 646 & 1,032 & 3,615 & 1.69 & 1.01 & 1.93 & 51.1 & 46.3 & 53.9 \\
\hline Argentina & 407 & 565 & 850 & 1.51 & 1.20 & 1.42 & 26.8 & 31.6 & 20.3 \\
\hline Brazil & 66 & 159 & 872 & 2.53 & 1.85 & 3.63 & 26.4 & 29.4 & 21.9 \\
\hline France & 353 & 844 & 3,224 & 2.55 & 2.85 & 3.22 & 47.8 & 41.3 & 54.1 \\
\hline Italy & 213 & 350 & 2,165 & 2.27 & 0.91 & 4.20 & 56.5 & 45.9 & 63.5 \\
\hline Netherlands & 288 & 699 & 2,166 & 2.31 & 1.97 & 2.94 & 70.5 & 57.3 & 74.2 \\
\hline Portugal & 116 & 168 & 1,155 & 2.32 & 1.14 & 3.95 & 46.8 & 17.8 & 76.2 \\
\hline Spain & 250 & 307 & 1,140 & 1.51 & 0.45 & 3.41 & 44.7 & 23.5 & 65.8 \\
\hline French-origin average & 242 & 442 & 1,653 & 2.14 & 1.48 & 3.25 & 45.6 & 35.3 & 53.7 \\
\hline Germany & 109 & 192 & 3,713 & 2.97 & 1.55 & 3.89 & 35.6 & 42.1 & 30.7 \\
\hline Japan & 92 & 214 & 2,228 & 3.47 & 1.82 & 5.48 & 84.7 & 52.6 & 108.4 \\
\hline German-origin average & 101 & 203 & 2,971 & 3.22 & 1.69 & 4.69 & 60.2 & 47.4 & 69.6 \\
\hline Denmark & 330 & 784 & 2,842 & 2.10 & 1.94 & 3.02 & 60.1 & 71.6 & 50.1 \\
\hline Finland & 228 & 514 & 3,085 & 2.33 & 1.70 & 3.20 & 62.1 & 82.6 & 43.0 \\
\hline Norway & 189 & 423 & 3,721 & 3.03 & 3.32 & 3.14 & 64.1 & 74.7 & 53.5 \\
\hline Sweden & 241 & 723 & 3,840 & 2.42 & 2.39 & 2.57 & 66.9 & 73.7 & 57.2 \\
\hline Scandinavian average & 247 & 611 & 3,372 & 2.47 & 2.34 & 2.98 & 63.3 & 75.7 & 51.0 \\
\hline Sample average & 322 & 592 & 2,864 & 2.24 & 1.59 & 3.05 & 52.8 & 48.8 & 55.0 \\
\hline
\end{tabular}

Notes: See text for data sources. Per capita incomes are reported for 1880, 1929, and 1990. Income growth rates and the ratio of broad money to GDP are averages of the available annual observations over the 1880-1997, 1880-1929 and 1945-94 periods. 
Table 1 shows the level of GDP, its growth rate, and the level of financial development by legal origin at selected times for our sample of 17 countries covering the period from 1880 to 1997. The data are taken from the World Bank's World Development Indicators for the post-1960 period. For earlier years they are from worksheets underlying Obstfeld and Taylor (2000), Bordo and Jonung (1987), Rousseau and Wachtel (1998), and Rousseau (1999). We measure financial development as broad money divided by GDP. This primarily reflects the size of a country's banking system, and as such will record high values for countries with more bank-based financial systems. Ideally we would like an additional measure of financial development such as the ratio of stock market capitalization to GDP that would record high values for more market-based systems, but observations are not readily available for this over the full time dimension of our study. Beck and Levine (2002, p. 40), however, report a correlation coefficient of 0.664 for averages of these market and bank-based measures from 1990 to 1995 in a cross-section of 115 countries, and so we believe that our use of broad money divided by GDP as the sole measure of financial development should reflect the size of an even more broadly-defined capital market reasonably well.

In contrast to La Porta et al., countries in our smaller sample with English legal origin do not appear to be more financially developed than those with French legal origin, especially from 1945 to 1994. The two German-origin countries (i.e., Germany and Japan), on the other hand, experience extraordinary postwar growth and considerable increases in financial depth with our bank-based measure. ${ }^{1}$ The Nordic countries experience a reversal from being the most financially developed in

\footnotetext{
${ }^{1}$ Beck and Levine (2004, pp. 13-14) note that Japan considered the French civil code in drafting their own commercial code of 1899, but that the German model prevailed because Japanese scholars were "attracted to the systematic theorizing of the German code and its emphasis on fitting the evolution of law into a country's historical context." It is interesting that the two countries in our sample with German legal origin both developed universal (i.e, bank-based) financial systems even though Japan had begun with a more U.S.-like (i.e., market-based) system in the $1880 \mathrm{~s}$.
} 
the 1880-1929 period to becoming the least developed in the postwar period, yet their growth rates are fairly stable across the sub-periods. A comparison of the level and growth rates of output across the sub-groupings indicates that, consistent with the theory of convergence, countries with the lowest growth rates tend to have the highest initial levels of income.

A closer comparison of the sample of countries in our study with those in La Porta et al. reveals why we do not see countries with French legal origin under-performing as might be expected. First, La Porta et al. include nine Latin American countries with French legal origins, while the only Latin American countries in our historical sample are Argentina and Brazil. ${ }^{2}$ Most of these countries today have low levels of financial development and low rates of economic growth relative to countries with English legal origin. Second, La Porta et al. include a number of Asian countries in the group with English legal origin that today have high levels of financial development and relatively rapid growth rates. ${ }^{3}$ The lack of many Latin American countries in our subset with French legal origin makes one country, the Netherlands, which had high levels of financial development and an average annual growth rate of 2.3 percent over the full sample period, exert considerable leverage on the averages in Table 1 and several of our later regression results. For example, excluding the Netherlands from Table 1 makes the average level of financial development for the French origin countries fall from 45.6 percent to 41.5 percent for $1880-1997$, from 35.3 percent to 31.6 percent for 1880 to 1929 , and from 53.7 percent to 50.3 percent for $1945-1994$, placing them considerably further below the sample average in all three periods. Since the Dutch financial system was established well before the Napoleonic era, it is also much less likely to have been affected by the

\footnotetext{
${ }^{2}$ The Latin American countries in La Porta et al. (1998) are Argentina, Brazil, Chile, Colombia, Ecuador, Mexico, Peru, Uruguay, and Venezuela.

${ }^{3}$ The Asian countries in La Porta et al. (1998) with English legal origin are Hong Kong, India, Malaysia, Singapore, and Thailand.
} 
French civil law tradition that it later adopted.

Overall, the summary statistics in Table 1 suggest that the country rankings of financial development by legal origin, when measured at different times across a century and for the 17 nowdeveloped economies that we consider, are reasonably close to those found by La Porta et al. in 1994. The lack of persistence in the patterns for the Scandinavian countries, however, is difficult to square with the "law and finance" theory, which suggests that legal origin, as a pre-determined proxy for the protection of property rights, should be correlated with subsequent levels of financial development whenever measured.

We next use a regression framework to determine whether legal origin matters for financial development. The OLS regressions reported in Table 2 include the average level of financial depth as the dependent variable measured over ten-year periods for 1880-1997 and over five-year periods for 1880-1929 and 1945-1994. ${ }^{4}$ The initial level of per capita income and the initial inflation rate, both measured at the start of each five or ten-year period appear on the right-hand side along with dummy variables for legal origin and time. We include inflation as a control variable because a growing literature (e.g., Boyd, Levine, and Smith, 2001; Rousseau and Wachtel 2002) suggests that high inflation, which is usually related to variable inflation, can lead to difficulties in nominal contracting and in turn dampen or even reverse financial development. Initial income appears on the right-hand side because we suspect that higher incomes are associated with more economic activity and a more than proportionate increase in the demand for financial assets and services. ${ }^{5}$

\footnotetext{
${ }^{4}$ These timing conventions are used throughout the paper in building the observational units that we study in our cross-country regression analysis.

${ }^{5}$ This specification is similar to one in which the long-run demand for money is driven by a number of institutional factors (see Bordo and Jonung 1987; Friedman and Schwartz 1982). In our framework, financial development is a strong determinant of the demand for money. Since there is no ideal measure of financial development covering all 17 countries over the time of our study, the ratio of broad money to GDP is called upon to serve this purpose.
} 
Table 2

OLS regressions of financial development on legal origin, 17 countries and excluding the Netherlands

\begin{tabular}{lcccccc}
\hline & \multicolumn{7}{c}{ Dependent variable: Broad money / GDP } \\
& \multicolumn{2}{c}{$1880-1997$} & $1880-1929$ & $1945-1994$ \\
Log of initial real per & 0.037 & 0.000 & $0.090^{* *}$ & $0.055^{* *}$ & -0.034 & -0.048 \\
capita GDP (1960 US\$) & $(1.09)$ & $(0.00)$ & $(4.03)$ & $(2.40)$ & $(-0.83)$ & $(1.17)$ \\
Initial inflation rate & $-0.001^{* *}$ & $-0.001^{* *}$ & 0.0005 & 0.0005 & $-0.002^{* *}$ & $-0.002^{* *}$ \\
& $(-2.76)$ & $(-2.65)$ & $(1.13)$ & $(1.31)$ & $(-4.68)$ & $(-4.34)$ \\
& -0.005 & -0.089 & 0.011 & -0.063 & 0.013 & -0.036 \\
French legal origin & $(-0.09)$ & $(-1.52)$ & $(0.28)$ & $(-1.55)$ & $(0.21)$ & $(-0.54)$ \\
& $0.193^{* *}$ & $0.152^{* *}$ & $0.176^{* *}$ & $0.117^{* *}$ & $0.193^{* *}$ & $0.184^{* *}$ \\
German legal origin & $(2.74)$ & $(2.20)$ & $(3.26)$ & $(2.19)$ & $(2.76)$ & $(2.63)$ \\
& $0.127^{* *}$ & $0.110^{* *}$ & $0.356^{* *}$ & $0.329^{* *}$ & -0.031 & -0.034 \\
Scandinavian legal origin & $(2.59)$ & $(2.30)$ & $(10.06)$ & $(9.51)$ & $(-0.58)$ & $(-0.64)$ \\
& .273 & .302 & 0.652 & 0.693 & .251 & .245 \\
$\mathrm{R}^{2}$ & $(195)$ & $(183)$ & $(165)$ & $(155)$ & $(166)$ & $(156)$ \\
(No. observations) & & & & & & \\
\hline
\end{tabular}

Notes: T-statistics are in parentheses. For each set of years, the first column reports the regression results for all 17 countries; the second column omits the Netherlands. The dependent variable is averaged over each decade for 1880-1997 and every five years for 1880-1929 and 1945-1994. The initial values of real per capita GDP and the inflation rate are taken from the first year of each period. Dummy variables for each five- or ten-year period are included in the regressions but not reported. * and ${ }^{* *}$ denote statistical significance at the 10 percent and 5 percent levels respectively.

The first column for each time period reports results for all 17 countries, while the second column omits the Netherlands. Controlling for inflation seems to be important over the full 18801997 and post-1945 periods, but not in the $1880-1929$ period. ${ }^{6}$ As suggested by our summary

\footnotetext{
${ }^{6}$ The lack of a negative and significant relationship between inflation and financial development for the 1880-1929 period can be attributed to inflation rates that were for the most part stationary before the first World War and our use of dummy variables for every five-year period that tend to control for more general inflation trends from 1915-29.
} 
statistics in Table 1, countries with French legal origin do not have lower levels of financial development than those with English legal origin when we use all of the countries, but with the Netherlands excluded have lower levels of financial development over the 1880-1997 and 1880-1929 periods, albeit at the 15 percent level only. As seen in Table 1, countries with German or Scandinavian legal origins outperform both English and French systems with our bank-based measure of financial development, especially for 1880-1929. Similar to La Porta et al. (1997), Scandinavian systems have less financial development in the postwar period, but in our extended sample the reversal from the past again clearly manifests.

Table 3 uses cross-country regressions to examine whether legal origin matters for growth when included with initial levels of GDP, financial depth, and dummy variables for the five or tenyear observation periods. ${ }^{7}$ The first column in each of the three panels shows the Rousseau and Sylla (2003) result that finance matters for growth whether tested with postwar data or with data starting in the latter half of the 19th century. None of the legal-origin variables are statistically significant at conventional levels for 1880-1997 or for 1880-1929, but the third column of each panel shows that finance loses much of its explanatory power for growth when legal origin appears in the regression. This suggests that if "legal origin" or some other country characteristics that the dummy variables are capturing matter for growth, they are probably acting more through financial development than as independent factors.

We are not the first to point out that the popular "law and finance" thesis may be wanting when taken to the available historical data. Rajan and Zingales (2003), for example, point out that

\footnotetext{
${ }^{7}$ We exclude inflation from the growth regressions because recent studies (e.g., Bruno and Easterly 1998; Rousseau and Wachtel 2002) show that any negative relationship between inflation and growth in cross-country data sets is driven by extreme observations such as hyper-inflations.
} 
Table 3

OLS regressions of growth on financial development and legal origin, 17 countries

\begin{tabular}{|c|c|c|c|c|c|c|}
\hline \multirow[b]{3}{*}{ Constant } & \multicolumn{6}{|c|}{ Dependent variable: Growth in real per capita GDP } \\
\hline & \multicolumn{2}{|c|}{$1880-1997$} & \multicolumn{2}{|c|}{$1880-1929$} & \multicolumn{2}{|c|}{$1945-1994$} \\
\hline & $\begin{array}{l}6.333^{* *} \\
(4.24)\end{array}$ & $\begin{array}{l}8.341^{* *} \\
(3.84)\end{array}$ & $\begin{array}{l}4.733^{* *} \\
(2.65)\end{array}$ & $\begin{array}{l}5.936^{*} \\
(1.89)\end{array}$ & $\begin{array}{l}9.941^{* *} \\
(4.29)\end{array}$ & $\begin{array}{c}11.559^{* *} \\
(3.42)\end{array}$ \\
\hline $\begin{array}{l}\text { Log of initial real per } \\
\text { capita GDP (1960 US\$) }\end{array}$ & $\begin{array}{l}-0.702^{* *} \\
(-3.78)\end{array}$ & $\begin{array}{l}-0.894^{* *} \\
(-3.54)\end{array}$ & $\begin{array}{l}-0.606^{* *} \\
(-2.12)\end{array}$ & $\begin{array}{l}-0.739 \\
(-1.62)\end{array}$ & $\begin{array}{l}-1.404^{* *} \\
(-4.97)\end{array}$ & $\begin{array}{l}-1.631^{* *} \\
(-4.12)\end{array}$ \\
\hline Initial broad money / GDP & $\begin{array}{l}1.311^{* *} \\
(2.30)\end{array}$ & $\begin{array}{l}0.753 \\
(1.27)\end{array}$ & $\begin{array}{l}3.009^{* *} \\
(2.77)\end{array}$ & $\begin{array}{l}2.504 \\
(1.59)\end{array}$ & $\begin{array}{l}3.570^{* *} \\
(5.38)\end{array}$ & $\begin{array}{l}3.287^{* *} \\
(4.98)\end{array}$ \\
\hline French legal origin & & $\begin{array}{l}-0.617 \\
(-1.46)\end{array}$ & & $\begin{array}{l}-0.275 \\
(-0.37)\end{array}$ & & $\begin{array}{l}0.009 \\
(0.01)\end{array}$ \\
\hline German legal origin & & $\begin{array}{l}0.618 \\
(1.15)\end{array}$ & & $\begin{array}{l}-0.509 \\
(-0.48)\end{array}$ & & $\begin{array}{l}1.900^{* *} \\
(2.71)\end{array}$ \\
\hline Scandinavian legal origin & & $\begin{array}{l}0.268 \\
(0.71)\end{array}$ & & $\begin{array}{l}0.147 \\
(0.18)\end{array}$ & & $\begin{array}{l}0.797 \\
(1.51)\end{array}$ \\
\hline $\begin{array}{l}\mathrm{R}^{2} \\
\text { (No. observations) }\end{array}$ & $\begin{array}{l}.333 \\
(195)\end{array}$ & $\begin{array}{l}.371 \\
(195)\end{array}$ & $\begin{array}{l}0.123 \\
(165)\end{array}$ & $\begin{array}{l}.127 \\
(165)\end{array}$ & $\begin{array}{l}0.416 \\
(166)\end{array}$ & $\begin{array}{l}.453 \\
(166)\end{array}$ \\
\hline
\end{tabular}

Notes: T-statistics in parentheses. The dependent variable is averaged over each decade for the 18801997 period and every five years for the 1880-1929 and 1945-1994 periods. Initial values of real per capita GDP are taken from the first year of each period. Dummy variables for each five- or ten-year period are included in the regressions but not reported. $*$ and $* *$ denote statistical significance at the 10 percent and 5 percent levels respectively.

several countries with French civil law traditions, including France, were more financially-developed in 1913, at least when measured by the relative sizes of their equity markets, than many common law countries, including the United States. One way to reconcile such reversals with the legal origins hypothesis would be to argue that French civil law, itself created in the 19th century, was well adapted to the economics of the time but not to business in the late 20th century. ${ }^{8}$ On the other hand,

\footnotetext{
${ }^{8}$ Lamoreaux and Rosenthal defend the French civil law system of the 19th century on the grounds that it was much more helpful to business at that time. Franks, Mayer, and Rossi (2005) make a similar point regarding British history, claiming that the common law system was the very reason
} 
relating the reversals more closely to a political story, such as those proposed by Rajan and Zingales (2003), Perotti and Von Thadden (2005) or Pagano and Volpin (2005) seems a potentially fruitful alternative approach to understanding how financial systems evolve and affect economic activity.

\section{The Political Environment, Finance, and Growth}

A large empirical literature (e.g., Barro 1991; Barro and Lee 1994; Alesina and Perotti 1994; Alesina et al. 1996, among others) indicates that political instability is associated with negative growth outcomes in large cross-sections of countries using postwar data. ${ }^{9}$ Political instability is associated with uncertainty about the climate for business returns. This tends to delay or reduce investment and in turn may slow entrepreneurial activity more generally. Relatively little is known about whether political instability affects financial development. If uncertainty about the business environment slows the demand for investment, however, it might just as easily affect the supply of funds and lead to reduced holdings of financial assets and less financial depth. In this section we examine links between political variables, finance, and growth from 1880 to 1997 using a database of political indicators compiled by Leblang $(2003,2004)$. The extended time period allows us to investigate the role of political factors over more than a century.

Leblang's database provides several measures of the political environment that are useful for our study. These include indicators for whether 1) a government is based on a parliamentary system, 2) the electoral system is based upon the principle of proportional representation, 3) decisions are made primarily by a single political party that holds a majority of offices, and 4) there is universal

why shareholder protection was so weak in the UK before 1945.

${ }^{9}$ Not all studies find a negative relationship between political instability and growth. For example, Campos and Nugent (2002) find in a cross section of countries covering the period from 1952 to 1980 that the negative relationship can be attributed largely to the presence of the African countries in their sample. 
female suffrage. Additional measures include the number of elections held each year and the number of revolutions or coups. Only the last measure, which has been used extensively in earlier crosscountry regression studies, can be seen as a direct proxy for political "instability." The others are more general indicators of the political environment that we believe may be related to financial development and growth. We do not hold particularly strong priors concerning the various political variables, but believe that policies involving the expropriation of individual property might be more easily pursued in countries that are less democratic, ${ }^{10}$ hold infrequent elections, deny suffrage to women, or are dominated by a single political party.

Table 4 shows conditional correlations between financial development, growth, and each of the political variables. In the left panel, financial depth is the dependent variable and each cell reports the coefficient and t-statistic (in parentheses) for the political variable listed in the left-hand column in an OLS specification that includes a constant, initial GDP, the initial inflation rate, dummy variables for time, and the single political variable as regressors. In other words, the left panel of Table 4 reports results from 17 separate regressions. The specifications in the right panel exclude inflation from the control set and use GDP growth as the dependent variable.

The regressions show that parliamentary or mixed systems (as opposed to presidential systems) and election systems based on proportional representation are related to higher levels of financial development over the full sample and both sub-periods. These two highly correlated political indicators $($ rho $=0.59)$ are also positively but not always statistically significantly linked

${ }^{10}$ Parliamentary systems and systems with elections based on proportional representation may be more closely related to the notion of "democracy" than presidential systems or systems where some smaller group or groups in the population have a disproportionate influence over laws and their enforcement. 
Table 4

OLS regressions of financial development and growth on individual political variables, 17 countries

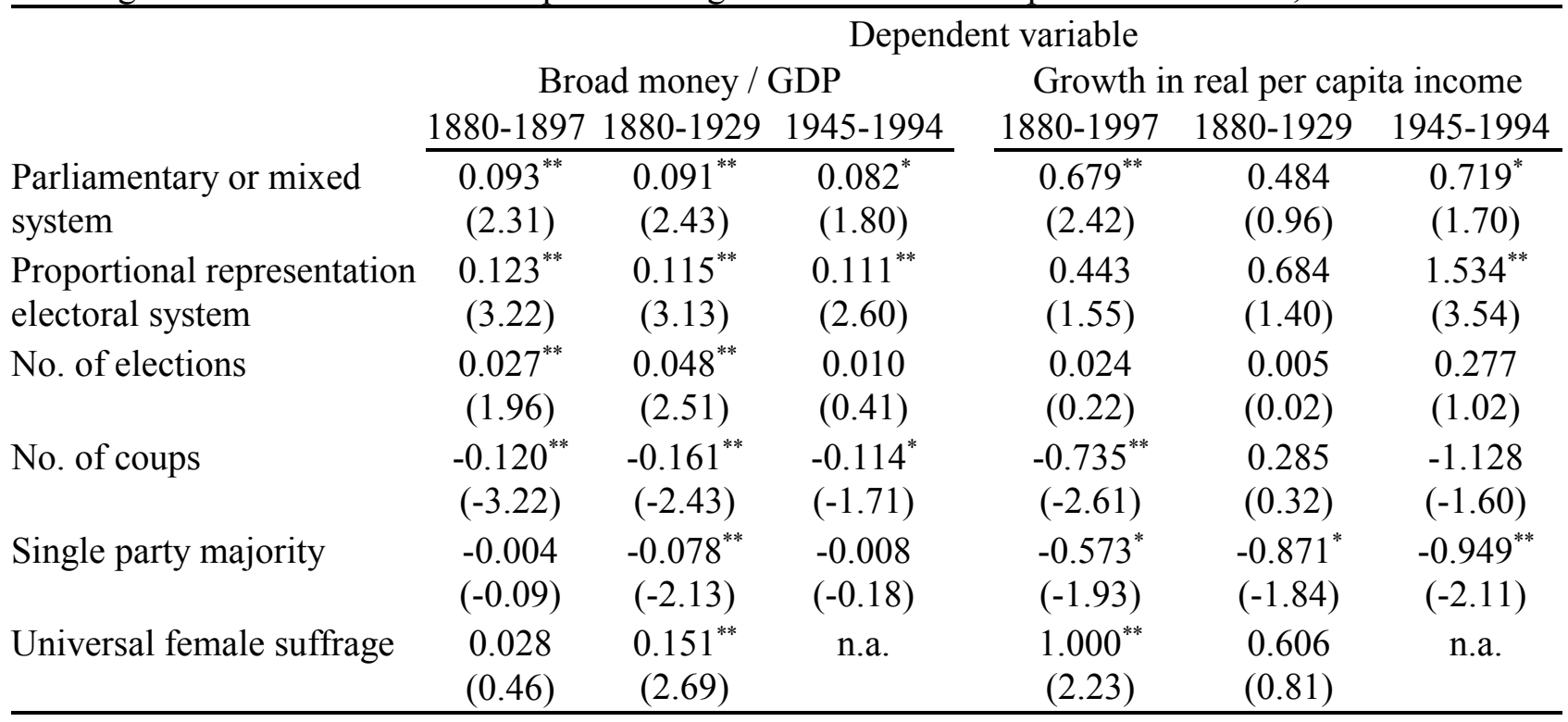

Notes: The table shows coefficients and t-statistics for the political variable listed in the left-hand column in separate cross-country regressions that include per capita income growth or financial depth on the left hand side. In addition to the single political variable, the right hand side of each equation includes the level of per capita GDP at the start of each ten-year (1880-1997) or five-year (1880-1929 and 1945-1994) period. The initial inflation rate is also included in the baseline equation when financial development is the dependent variable. The regressions include dummy variables for each period that are not reported. * and ** denote statistical significance at the 10 percent and 5 percent levels respectively.

with growth. ${ }^{11}$ Frequent elections are positively related to financial development for 1880-1997 and 1880-1929, but not with GDP growth. Coups are negatively correlated with financial development

${ }^{11}$ The countries in our sample with presidential systems throughout the 1880-1997 period are Argentina, Brazil, Italy, and the United States. None of the four had proportional representation except Italy, which adopted it in 1920. Countries that switched from presidential to parliamentary or mixed systems are Germany 1919, Japan 1947, the Netherlands 1916, Norway 1906, Portugal 1912, Spain 1978, and Sweden 1917. Germany, Japan, Portugal and Spain switched to proportional representation at the same times as their parliamentary switches. The Netherlands and Norway switched to parliamentary systems in 1918 and 1921 respectively, while Sweden had proportional representation throughout. Countries with parliamentary or mixed systems throughout are Australia, Canada, Denmark, Finland, France, and the United Kingdom. Among these, only the United Kingdom had proportional representation throughout, while France had it in all years other than 1945-57. Canada had a majoritarian system. Australia switched to proportional representation in 1942, Denmark in 1916, and Finland in 1907. 
and, consistent with earlier cross-country growth regressions, usually with GDP growth as well, though the coefficient is statistically significant at the five percent level when we consider the full 1880-1997 period only. Periods when governments operate under a single party majority are generally ones of lower growth, while universal female suffrage is related to more financial development for 1880-1929 and higher conditional growth rates for 1880-1997. ${ }^{12}$ Overall, Table 4 indicates that political variables are potentially useful for explaining financial development and growth, but perhaps more so for financial development.

Our finding that presidential systems are associated with less financial development than parliamentary or mixed systems is driven by the Latin American countries in our sample, both of which have presidential systems. ${ }^{13}$ For example, if we remove Argentina and Brazil from the regressions reported in the first line of Table 4, we find that parliamentary or mixed systems no longer have significantly larger financial sectors than presidential systems for all three sub-periods, though their conditional growth rates for 1880-1997 remain significantly higher at the ten percent level. $^{14}$

Table 5 extends our analysis of political variables to a multiple regression framework in which all of the political variables enter each specification together. In all cases, proportional

${ }^{12}$ We do not include the dummy variables for universal female suffrage in our regressions for the postwar period because by 1946, with the exceptions of Portugal (1975) and Spain (1976), women had the right to vote in all of the countries in our sample.

${ }^{13}$ That the Latin American countries drive our result that presidential systems perform worse than parliamentary or mixed ones should not come as a surprise. Even though these countries adopted the U.S. model when they set up their financial systems in the 19th century, their systems never worked like they did in the United States (i.e., elections were rigged, suffrage was limited, judges were bribed, and presidents were removed by coups.

${ }^{14}$ We also experimented with a separate dummy variable for the United States, and found that, as expected, the rest of the presidential systems had even lower levels of financial development compared to parliamentary or mixed systems. 
Table 5

OLS multiple regressions of financial development and growth on all political variables, 17 countries

\begin{tabular}{|c|c|c|c|c|c|c|}
\hline & Bro & d money / & DP & Growth i & eal per cap & ta income \\
\hline & $1880-1897$ & $1880-1929$ & 1945-1994 & $1880-189$ & $1880-1929$ & 1945-1994 \\
\hline Initial GDP per capita & $\begin{array}{l}0.022 \\
(0.73)\end{array}$ & $\begin{array}{l}0.023 \\
(0.92)\end{array}$ & $\begin{array}{l}0.008 \\
(0.23)\end{array}$ & $\begin{array}{l}-1.127^{* *} \\
(-4.90)\end{array}$ & $\begin{array}{l}-0.852^{* *} \\
(-2.48)\end{array}$ & $\begin{array}{l}-1.795^{* *} \\
(-5.20)\end{array}$ \\
\hline Initial broad money / GDP & n.a. & n.a. & n.a. & $\begin{array}{l}1.138^{*} \\
(1.90)\end{array}$ & $\begin{array}{l}2.777^{* *} \\
(2.29)\end{array}$ & $\begin{array}{l}3.127^{* *} \\
(4.49)\end{array}$ \\
\hline Initial inflation rate & $\begin{array}{l}-0.001^{* *} \\
(-2.10)\end{array}$ & $\begin{array}{l}-0.000 \\
(-0.19)\end{array}$ & $\begin{array}{l}-0.001^{* *} \\
(-2.47)\end{array}$ & n.a. & n.a. & n.a. \\
\hline $\begin{array}{l}\text { Parliamentary or mixed } \\
\text { system }\end{array}$ & $\begin{array}{l}0.038 \\
(0.85)\end{array}$ & $\begin{array}{l}0.038 \\
(0.95)\end{array}$ & $\begin{array}{l}-0.032 \\
(-0.50)\end{array}$ & $\begin{array}{l}0.616^{*} \\
(1.83)\end{array}$ & $\begin{array}{l}0.168 \\
(0.32)\end{array}$ & $\begin{array}{l}0.106 \\
(0.17)\end{array}$ \\
\hline $\begin{array}{l}\text { Proportional representation } \\
\text { electoral system }\end{array}$ & $\begin{array}{l}0.105^{* *} \\
(2.35)\end{array}$ & $\begin{array}{l}0.085^{* *} \\
(2.22)\end{array}$ & $\begin{array}{l}0.152^{* *} \\
(2.33)\end{array}$ & $\begin{array}{l}-0.268 \\
(-0.78)\end{array}$ & $\begin{array}{l}0.269 \\
(0.50)\end{array}$ & $\begin{array}{l}0.773 \\
(1.21)\end{array}$ \\
\hline No. of elections & $\begin{array}{l}0.028^{* *} \\
(1.99)\end{array}$ & $\begin{array}{l}0.032^{*} \\
(1.68)\end{array}$ & $\begin{array}{l}0.025 \\
(0.91)\end{array}$ & $\begin{array}{l}-0.082 \\
(-0.75)\end{array}$ & $\begin{array}{l}-0.147 \\
(-0.56)\end{array}$ & $\begin{array}{l}0.256 \\
(0.98)\end{array}$ \\
\hline No. of coups & $\begin{array}{l}-0.094^{* *} \\
(-2.47)\end{array}$ & $\begin{array}{l}-0.147^{* *} \\
(-2.31)\end{array}$ & $\begin{array}{l}-0.115 \\
(-1.61)\end{array}$ & $\begin{array}{l}-0.506^{*} \\
(-1.73)\end{array}$ & $\begin{array}{l}0.575 \\
(0.65)\end{array}$ & $\begin{array}{l}0.044 \\
(0.06)\end{array}$ \\
\hline Single party majority & $\begin{array}{l}0.043 \\
(1.03)\end{array}$ & $\begin{array}{l}-0.049 \\
(-1.31)\end{array}$ & $\begin{array}{r}0.069 \\
(1.44)\end{array}$ & $\begin{array}{l}-0.349 \\
(-1.14)\end{array}$ & $\begin{array}{l}-0.543 \\
(-1.08)\end{array}$ & $\begin{array}{l}-0.722 \\
(-1.55)\end{array}$ \\
\hline Universal female suffrage & $\begin{array}{l}-0.030 \\
(-0.47)\end{array}$ & $\begin{array}{l}0.090 \\
(1.55)\end{array}$ & n.a. & $\begin{array}{l}0.764 \\
(1.61)\end{array}$ & $\begin{array}{l}0.118 \\
(0.14)\end{array}$ & n.a. \\
\hline $\mathrm{R} 2$ & .287 & 0.312 & 0.191 & .384 & 0.143 & 0.450 \\
\hline No. observations & $(195)$ & $(165)$ & $(166)$ & $(195)$ & $(165)$ & $(166)$ \\
\hline
\end{tabular}

Notes: The table shows coefficients and t-statistics (in parentheses) for the variables listed in the lefthand column in cross-country regressions that include per capita income growth or financial depth on the left hand side. Initial values are measured at the start of each ten-year (1880-1997) or five-year (1880-1929 and 1945-1995) period. Dummy variables for each period are included in the regressions but are not reported. * and $* *$ denote statistical significance at the 10 percent and 5 percent levels respectively.

representation electoral systems are positively and significantly related to financial development.

Perhaps surprisingly, the indicator for a parliamentary or mixed system is not statistically significant even though it was when entered as the sole political variable in Table 4. This difference is likely due to the relatively high correlation and resulting collinearity between parliamentary governments 
and proportional electoral systems. ${ }^{15}$ The frequency of elections is positively related to financial development in the 1880-1997 and 1880-1929 periods, and the number of revolutions or coups is negatively related to financial development in all sub-periods. Universal female suffrage has positive but not quite statistically significant effects on financial development for 1880-1929 and on growth for 1880-1997. Interestingly, after conditioning on financial development, the growth regressions in the right panel of Table 5 show little role for any of the political variables other than revolutions and coups, which are negatively related to growth over the 1880-1997 period at the ten percent level only. These results suggest that the primary channel through which the political environment affects growth may involve the accumulation and allocation of financial capital.

Our findings relate to those of Pagano and Volpin (2005), who investigate the relationship between proportional representation and the protection of shareholders' rights. They show that countries with proportional representation tend to elect coalitions catering more to the preferences of social groups with homogenous preferences, that is entrepreneurs and employees, than to the residual group that includes passive minority shareholders. Under such a system, changes in a given coalition's political platform tend to favor groups with homogenous preferences that can be swayed as a block. On the other hand, under a majoritarian system it is precisely the non-ideological residuals in pivotal districts whose votes are keenly sought. A proportional representation system that has the potential to weaken the rights of minority shareholders is less likely to draw equity funds from the public, but at the same time can promote entrepreneurial activity and business startups by

\footnotetext{
${ }^{15}$ When we remove Argentina and Brazil from the group with non-proportional systems, countries with proportional electoral systems remain associated with higher levels of financial development that are statistically significant at the ten percent level for 1880-1997 and the five percent level for 1880-1929. For 1945-1994, having a proportional representation system no longer seems to matter for financial development, but parliamentary or mixed systems become negatively related to financial development, though not quite at the ten percent level.
} 
benefitting those shareholders who gain control initially. Though these authors do not relate their model to financial development directly, it appears that proportional representation could have opposite and competing effects on finance, with the benefits of entrepreneurship and employee savings generating a demand for finance weighing against the potential for reduced shareholder rights to lower investment. Our results seem consistent with the former influence dominating.

Flandreau and Zumer (2004, pp. 34-7) also argue that democratic institutions such as parliamentary governments, proportional representation, and frequent elections can bolster a nation's reputation for fiscal responsibility in the world financial community, thereby lowering interest rate spreads and fostering economic growth through financial development. This intuition is reminiscent of the analysis of England's Glorious Revolution of 1688 by North and Weingast (1989), and is for the most part consistent with the evidence in our regressions. ${ }^{16}$

\section{Did Non-Legal and Non-Political Factors Matter?}

In this section we consider how much of financial development and growth can be explained jointly by the legal origin and political variables and, in particular, how much remains unexplained. If these variables do indeed capture deep fundamentals such as the ability and willingness to protect property rights, and these are truly the driving forces behind financial development, then we should

\footnotetext{
${ }^{16}$ On the other hand, proportional representation systems could lead to the risk of choosing a government that imposes confiscatory taxes that hurt both shareholders and entrepreneurs, as was the case with France over the interwar period. A number of European countries with proportional representation systems at that time were nearly paralyzed by conflicts over how to pay for the war. This led to social unrest and frequent changes in political leadership. Hyperinflations occurred in Austria, Germany, and Hungary, and high inflations occurred in France, Belgium, and other countries (see Eichengreen 1992). Political turnover was also important in the early post-WWII period in countries with weak proportional representation systems. This opens the possibility that the post-1945 recovery, the Marshall plan (1948-52) and the convergence of real incomes that ensued up through 1973 may explain the high levels of financial development and growth seen in many European countries with proportional representation but not necessarily stable governments that were decimated by the war.
} 
Table 6

OLS regressions of financial development on legal origin and political variables, 17 countries and excluding the Netherlands

\begin{tabular}{|c|c|c|c|c|c|c|}
\hline \multirow[b]{3}{*}{$\begin{array}{l}\text { Log of initial real per } \\
\text { capita GDP }\end{array}$} & \multicolumn{6}{|c|}{ Dependent variable: Broad money / GDP } \\
\hline & \multicolumn{2}{|c|}{$1880-1997$} & \multicolumn{2}{|c|}{$1880-1929$} & \multicolumn{2}{|c|}{ 1945-1994 } \\
\hline & $\begin{array}{l}0.018 \\
(0.55)\end{array}$ & $\begin{array}{l}-0.011 \\
(-0.31)\end{array}$ & $\begin{array}{l}0.077^{* *} \\
(3.40)\end{array}$ & $\begin{array}{l}0.041^{*} \\
(1.77)\end{array}$ & $\begin{array}{l}-0.030 \\
(-0.76)\end{array}$ & $\begin{array}{l}-0.039 \\
(-0.94)\end{array}$ \\
\hline Initial inflation rate & $\begin{array}{l}-0.001^{* *} \\
(-2.33)\end{array}$ & $\begin{array}{l}-0.001^{* *} \\
(-2.30)\end{array}$ & $\begin{array}{l}0.001 \\
(1.12)\end{array}$ & $\begin{array}{l}0.001 \\
(1.36)\end{array}$ & $\begin{array}{l}-0.002^{* *} \\
(-3.47)\end{array}$ & $\begin{array}{l}-0.002^{* *} \\
(-3.38)\end{array}$ \\
\hline French legal origin & $\begin{array}{l}-0.011 \\
(-0.20)\end{array}$ & $\begin{array}{l}-0.083 \\
(-1.40)\end{array}$ & $\begin{array}{l}-0.006 \\
(-0.14)\end{array}$ & $\begin{array}{l}-0.081^{* *} \\
(-2.03)\end{array}$ & $\begin{array}{l}0.014 \\
(0.21)\end{array}$ & $\begin{array}{l}-0.023 \\
(-0.32)\end{array}$ \\
\hline German legal origin & $\begin{array}{l}0.153^{* *} \\
(2.19)\end{array}$ & $\begin{array}{l}0.124^{*} \\
(1.80)\end{array}$ & $\begin{array}{l}0.157^{* *} \\
(2.87)\end{array}$ & $\begin{array}{l}0.098^{*} \\
(1.83)\end{array}$ & $\begin{array}{l}0.138^{*} \\
(1.90)\end{array}$ & $\begin{array}{l}0.140^{*} \\
(1.90)\end{array}$ \\
\hline Scandinavian legal origin & $\begin{array}{l}0.077 \\
(1.51)\end{array}$ & $\begin{array}{l}0.072 \\
(1.43)\end{array}$ & $\begin{array}{l}0.330^{* *} \\
(9.01)\end{array}$ & $\begin{array}{l}0.301^{* *} \\
(8.45)\end{array}$ & $\begin{array}{l}-0.085 \\
(-1.45)\end{array}$ & $\begin{array}{l}-0.079 \\
(-1.34)\end{array}$ \\
\hline $\begin{array}{l}\text { Proportional representation } \\
\text { electoral system }\end{array}$ & $\begin{array}{l}0.087^{* *} \\
(2.18)\end{array}$ & $\begin{array}{l}0.068^{*} \\
(1.72)\end{array}$ & $\begin{array}{l}0.056^{* *} \\
(2.21)\end{array}$ & $\begin{array}{l}0.065^{* *} \\
(2.66)\end{array}$ & $\begin{array}{l}0.119^{* *} \\
(2.44)\end{array}$ & $\begin{array}{l}0.094^{*} \\
(1.85)\end{array}$ \\
\hline Number of elections & $\begin{array}{l}0.019 \\
(1.42)\end{array}$ & $\begin{array}{l}0.016 \\
(1.21)\end{array}$ & $\begin{array}{l}-0.002 \\
(-0.13)\end{array}$ & $\begin{array}{l}0.000 \\
(0.01)\end{array}$ & $\begin{array}{l}0.018 \\
(0.72)\end{array}$ & $\begin{array}{l}0.009 \\
(0.34)\end{array}$ \\
\hline $\begin{array}{l}\text { Number of revolutions } \\
\text { or coups }\end{array}$ & $\begin{array}{l}-0.072^{*} \\
(-1.95)\end{array}$ & $\begin{array}{l}-0.063^{*} \\
(-1.72)\end{array}$ & $\begin{array}{l}-0.075^{*} \\
(-1.67)\end{array}$ & $\begin{array}{l}-0.068 \\
(-1.59)\end{array}$ & $\begin{array}{l}-0.075 \\
(-1.12)\end{array}$ & $\begin{array}{l}-0.075 \\
(-1.11)\end{array}$ \\
\hline $\begin{array}{l}\mathrm{R}^{2} \\
\text { (No. observations) }\end{array}$ & $\begin{array}{c}.321 \\
(195)\end{array}$ & $\begin{array}{c}.337 \\
(183)\end{array}$ & $\begin{array}{c}.670 \\
(165)\end{array}$ & $\begin{array}{c}.715 \\
(155)\end{array}$ & $\begin{array}{l}.294 \\
(166)\end{array}$ & $\begin{array}{c}.275 \\
(156)\end{array}$ \\
\hline
\end{tabular}

Notes: T-statistics are in parentheses. For each set of years, the first column reports the regression results for all 17 countries; the second column omits the Netherlands. The dependent variable is averaged over each decade for 1880-1997 and every five years for 1880-1929 and 1945-1994. The initial values of real per capita GDP and the inflation rate are measured in the first year of each five or ten-year time period. Dummy variables for each five- or ten-year period are included in the regressions but not reported. ${ }^{*}$ and $* *$ denote statistical significance at the 10 percent and 5 percent levels respectively.

expect the legal and political variables to explain a large portion of the cross-sectional variation in financial development and to explain growth jointly as well as financial development itself.

Table 6 reports results from a set of multiple regression specifications that combine 
indicators for legal origin with the political variables from Table 5 that are most robustly correlated with financial development (i.e., proportional representation, number of elections, and number of revolutions or coups). The first column for each time period includes all 17 countries in our sample; the second column excludes the Netherlands. Financial development is the dependent variable. Once again, countries with French legal origin have lower conditional levels of financial development in the 1880-1929 period than countries with English legal origin, but the differences are not statistically significant unless we remove the Netherlands from the sample. German legal systems do better, and the reversal of signs for the Scandinavian countries across the 1880-1929 and 1945-94 sub-periods is even more apparent here than in Table 2. The results do suggest, however, that the political environment matters for financial development and that these effects are relatively stable over time.

In Table 7 we add the indicator for a parliamentary or mixed system back into the regressions and experiment with removing the two Latin American countries and the Netherlands from our sample. Once again, the first column for each time period contains regression estimates that include all 17 countries, but this time the second columns omit Argentina, Brazil, and the Netherlands. When we do this for the 1880-1929 period, we still find that countries with proportional representation tend to be more financially developed, even when the Latin American countries are omitted.

For the 1945-97 period, however, we find that the indicator for proportional representation is no longer significant in the reduced sample, while parliamentary or mixed systems are associated with lower financial development and frequent elections are related more to financial development. Here it seems that excluding the Latin American countries (and their presidential systems) encourages a less sanguine view of the benefits of parliamentary government. At the same time, the frequency of elections, a variable related to "democracy", is now positively related to financial development at the five percent level while the coefficient on the indicator for proportional 
Table 7

OLS regressions of financial development on legal origin and political variables, 17 countries and excluding the Netherlands, Argentina, and Brazil

\begin{tabular}{|c|c|c|c|c|c|c|}
\hline \multirow[b]{3}{*}{$\begin{array}{l}\text { Log of initial real per } \\
\text { capita GDP }\end{array}$} & \multicolumn{6}{|c|}{ Dependent variable: Broad money / GDP } \\
\hline & \multicolumn{2}{|c|}{$1880-1997$} & \multicolumn{2}{|c|}{$1880-1929$} & \multicolumn{2}{|c|}{ 1945-1994 } \\
\hline & $\begin{array}{l}0.016 \\
(0.49)\end{array}$ & $\begin{array}{l}-0.039 \\
(-0.95)\end{array}$ & $\begin{array}{l}0.078^{* *} \\
(3.41)\end{array}$ & $\begin{array}{l}0.105^{* *} \\
(2.96)\end{array}$ & $\begin{array}{l}-0.030 \\
(-0.76)\end{array}$ & $\begin{array}{l}-0.141 \\
(-3.42)\end{array}$ \\
\hline Initial inflation rate & $\begin{array}{l}-0.001^{* *} \\
(-2.25)\end{array}$ & $\begin{array}{l}-0.000 \\
(-0.32)\end{array}$ & $\begin{array}{l}0.000 \\
(0.94)\end{array}$ & $\begin{array}{l}0.000 \\
(0.71)\end{array}$ & $\begin{array}{l}-0.002^{* *} \\
(-3.43)\end{array}$ & $\begin{array}{l}-0.002^{* *} \\
(-3.57)\end{array}$ \\
\hline French legal origin & $\begin{array}{l}-0.005 \\
(-0.08)\end{array}$ & $\begin{array}{l}-0.050 \\
(-0.72)\end{array}$ & $\begin{array}{l}-0.011 \\
(-0.27)\end{array}$ & $\begin{array}{l}-0.020 \\
(-0.39)\end{array}$ & $\begin{array}{l}0.017 \\
(0.25)\end{array}$ & $\begin{array}{l}-0.032 \\
(-0.46)\end{array}$ \\
\hline German legal origin & $\begin{array}{l}0.157^{* *} \\
(2.22)\end{array}$ & $\begin{array}{l}0.100 \\
(1.33)\end{array}$ & $\begin{array}{l}0.151^{* *} \\
(2.66)\end{array}$ & $\begin{array}{l}0.190^{* *} \\
(2.69)\end{array}$ & $\begin{array}{l}0.138^{*} \\
(1.89)\end{array}$ & $\begin{array}{l}0.215^{* *} \\
(3.19)\end{array}$ \\
\hline Scandinavian legal origin & $\begin{array}{l}0.078 \\
(1.53)\end{array}$ & $\begin{array}{l}0.080 \\
(1.51)\end{array}$ & $\begin{array}{l}0.329^{* *} \\
(8.92)\end{array}$ & $\begin{array}{l}0.349^{* *} \\
(8.28)\end{array}$ & $\begin{array}{l}-0.085 \\
(-1.45)\end{array}$ & $\begin{array}{l}0.017 \\
(0.32)\end{array}$ \\
\hline Parliamentary or mixed & $\begin{array}{l}0.018 \\
(0.40)\end{array}$ & $\begin{array}{l}-0.017 \\
(-0.36)\end{array}$ & $\begin{array}{l}-0.011 \\
(-0.39)\end{array}$ & $\begin{array}{l}-0.018 \\
(-0.62)\end{array}$ & $\begin{array}{l}0.011 \\
(0.18)\end{array}$ & $\begin{array}{l}-0.129^{* *} \\
(-2.16)\end{array}$ \\
\hline $\begin{array}{l}\text { Proportional representation } \\
\text { electoral system }\end{array}$ & $\begin{array}{l}0.079^{*} \\
(1.74)\end{array}$ & $\begin{array}{l}0.022 \\
(0.46)\end{array}$ & $\begin{array}{l}0.059^{* *} \\
(2.21)\end{array}$ & $\begin{array}{l}0.059^{* *} \\
(2.28)\end{array}$ & $\begin{array}{l}0.112^{*} \\
(1.85)\end{array}$ & $\begin{array}{l}0.017 \\
(0.28)\end{array}$ \\
\hline Number of elections & $\begin{array}{l}0.020 \\
(1.44)\end{array}$ & $\begin{array}{l}0.022 \\
(1.51)\end{array}$ & $\begin{array}{l}-0.002 \\
(-0.17)\end{array}$ & $\begin{array}{l}-0.009 \\
(-0.65)\end{array}$ & $\begin{array}{l}0.018 \\
(0.69)\end{array}$ & $\begin{array}{l}0.054^{* *} \\
(2.11)\end{array}$ \\
\hline $\begin{array}{l}\text { Number of revolutions } \\
\text { or coups }\end{array}$ & $\begin{array}{l}-0.072^{*} \\
(-1.93)\end{array}$ & $\begin{array}{l}-0.089^{*} \\
(-1.65)\end{array}$ & $\begin{array}{l}-0.074^{*} \\
(-1.66)\end{array}$ & $\begin{array}{l}-0.103^{* *} \\
(-2.26)\end{array}$ & $\begin{array}{l}-0.075 \\
(-1.12)\end{array}$ & $\begin{array}{l}0.048 \\
(0.36)\end{array}$ \\
\hline $\begin{array}{l}\mathrm{R}^{2} \\
\text { (No. observations) }\end{array}$ & $\begin{array}{l}.322 \\
(195)\end{array}$ & $\begin{array}{l}.292 \\
(160)\end{array}$ & $\begin{array}{l}.671 \\
(165)\end{array}$ & $\begin{array}{c}.738 \\
(136)\end{array}$ & $\begin{array}{l}.294 \\
(166)\end{array}$ & $\begin{array}{l}.354 \\
(136)\end{array}$ \\
\hline
\end{tabular}

Notes: T-statistics are in parentheses. For each set of years, the first column reports the regression results for all 17 countries; the second column omits Argentina, Brazil, and the Netherlands. The dependent variable is averaged over each decade for 1880-1997 and every five years for 1880-1929 and 1945-1994. The initial values of real per capita GDP and the inflation rate are measured in the first year of each five or ten-year time period. Dummy variables for each five- or ten-year period are included in the regressions but not reported. * and ** denote statistical significance at the 10 percent and 5 percent levels respectively.

representation remains positive but loses statistical significance. Overall the findings in Table 7 still suggest that factors associated with democracy such as proportional elections and frequent elections 
matter for financial development, even after removing the Latin American countries, and especially for 1880-1929.

We turn next to how much of the finance-growth relationship remains unexplained by indicators for legal origin and the political environment using a set of instrumental variables (IV) regressions. The first two columns of Table 8 take a two-stage least squares approach that extracts the pre-determined component of financial development in the first stage and then effectively inserts the fitted value in the standard growth specification. The regressions reported in the first column (as in Rousseau and Sylla 2003) use the level of financial development at the start of each five or tenyear observation period as the instrument, while the over-identified regressions reported in the second column use the dummy variables for legal origin and the robust political indicators as instruments. The regressions in the second column indicate a stronger relationship between finance and growth for all sample periods. This suggests that the dummies for legal origin and the political environment are better instruments for financial development than the initial level of finance, which had become a something of a standard instrument. ${ }^{17}$ Further, the results suggest that the deeper fundamentals, such as the political variables, are able to "cut through" the noise in standard measures of financial development to isolate the portion that matters for growth.

The regressions reported in the third column of Table 8 focus on how much of financial development's explanatory power for growth remains unexplained by the legal and political indicators. To do this, we use the first-stage residuals from the regression reported in the second column in place of finance as a regressor in the standard growth regression. In other words, the residuals represent the component of financial development that is not explained by predetermined

\footnotetext{
${ }^{17}$ Hansen tests for each of the over-identified specifications in Table 8 do not reject the validity of the political and legal variables as instruments for financial development at conventional significance levels.
} 
Table 8. Instrumental variables growth regressions

1880-1997

Log of initial real per

capita GDP (1960 US\$)

Broad money / GDP
Dependent variable: Percent growth of real per capita GDP $-0.695^{* *} \quad-0.822^{* *} \quad-0.639^{* *}$ $(-3.79) \quad(-4.05) \quad(-3.44)$

$1.304^{* *} \quad 4.546^{* *}$

(2.31) (3.42)

Residuals from first stage

$\mathrm{R}^{2}$

.348

.242

.322

(No. observations)

(194)

(194)

(194)

$$
\text { 1880-1929 }
$$

Log of initial real per

$-0.604^{* *} \quad-0.617^{* *}$

$-0.393$

capita GDP

$(-2.11)$

$(-2.11)$

$(-1.37)$

Broad money / GDP

Residuals from first stage

$7.134^{* *}$

(2.66)

$$
\mathrm{R}^{2}
$$

.124

.124

.046

(No. observations)

(165)

(165)

(165)

\section{5-1994}

Log of initial real per

$-1.444^{* *}$

$-1.446^{* *}$

$-1.441^{* *}$

capita GDP

$(-4.63)$

$(-4.07)$

$(-4.33)$

Broad money / GDP

$4.354^{* *} \quad 8.017^{* *}$

(4.88)

(3.50)

Residuals from first stage

5.215

(4.58)

$\mathrm{R}^{2}$

(No. observations)

\begin{tabular}{rr}
.290 & .076 \\
$(166)$ & $(166)$ \\
\hline
\end{tabular}

.191

(166)

The table reports coefficients from IV regressions with t-statistics in parentheses. All data items are period averages covering the 1880's through the 1990's. Period dummies are included in all regressions but are not reported. $*$ and $* *$ denote statistical significance at the 10 percent and 5 percent levels respectively. 
legal and political variables. Since these residuals may contain components that are affected by shocks that also affect contemporaneous output, we instrument it with the initial value of financial development, which is pre-determined. ${ }^{18}$ The results show that the unexplained component of financial development retains a large and statistically significant correlation with subsequent growth. This suggests that the protection of property rights and a favorable political environment, though conducive to financial development, may not be necessary for the finance-growth nexus to operate.

\section{Conclusion}

Cross-country investigations of the role of deep institutional fundamentals in the process of financial development have been fruitful extensions of a literature that has for decades maintained that financial factors can affect real outcomes. Probing this new research direction using historical data for a smaller group of now-developed economies, we find that relationships between the origin of a country's legal system and financial development that are roughly consistent with earlier findings but are not persistent over time. On the other hand, we do find that political variables such as proportional representation election systems, frequent elections, and infrequent revolutions or coups are consistent with larger financial sectors and higher conditional rates of economic growth.

We posit an underlying story to relate legal and political factors to financial development. When we control for inflation and time periods with dummy variables in the pre-1929 period, both

\footnotetext{
${ }^{18}$ Our two-stage regressions fall under "Model 4" of Pagan (1984, p. 232), meaning that the standard error of the coefficient on our generated regressor in the second-stage regression is valid for inference because 1) the generated regressor is an unlagged residual, 2) the anticipated component of financial development does not appear as a regressor in the second stage, and 3) the other right-hand side variable in the second stage (i.e., initial GDP) also appears in the first stage. Inference on the importance of the residual in the second stage are the same whether we estimate the second stage by OLS or by using the predetermined initial value of financial development as an instrument for the first-stage residual.
} 
legal and political variables seem to matter. Interestingly, in the post-1945 period, much of what is going on, including the Marshall Plan and the recovery from World War II, is outside of our regression analysis. Some countries in continental Europe, for example, that found themselves decimated by the war, saw frequent changes in political leadership driven by inherent instabilities associated with a proportional representation systems, but at the same time saw a good deal of financial development and growth in the course of rebuilding. The modern period (i.e., 1970 to the present) is probably more like the late 19th century. It might be interesting next to relate these results to the historical evolution that underlies them.

Despite our finding that indicators corresponding with legal origins and political factors explain a good part of the cross-sectional variation in financial development, there remains a substantial component of financial development that is correlated with growth and yet not related to these measures of deeper fundamentals. This suggests that, like Bell and Rousseau (2001) showed for post-independence India, having a deep and well-developed financial sector can have benefits for long-term growth even in the absence of strong institutional underpinnings that ostensibly protect property rights. This is not to say that sound institutions are not an important ingredient in an ideally growth-enhancing financial sector. Indeed, the absence of the sound and deep fundamentals (as measured here) may influence the sustainability of finance-driven growth, i.e., such countries may be more susceptible to serious financial crises. This is also a subject for future research. Rather, we suggest that research designs that pursue the "property rights" channel along with other channels such as capital accumulation and the overcoming of indivisibilities in investment will in the end help us to more fully understand how and why finance matters for growth. 


\section{References}

Acemoglu, Daron, Simon Johnson, and James A. Robinson. 2001. The colonial origins of comparative economic development: An empirical investigation. American Economic Review 91 (5): 1369-1401.

Alesina, Alberto, and Roberto Perotti. 1994. The political economy of economic growth: A critical survey of the recent literature. World Bank Economic Review 8 (3): 351-71.

Alesina, Alberto, Sule Ozer, Nouriel Roubini, and Phillip Swagel. 1996. Political instability and economic growth. Journal of Economic Growth 1 (2): 189-211.

Barro, Robert J. 1991. Economic growth in a cross section of countries. Quarterly Journal of Economics 56: 407-43.

Barro, Robert J., and Jong-Wha Lee. 1994. Sources of economic growth. Carnegie-Rochester Conference Series on Public Policy 40: 1-46.

Beck, Thorsten, and Ross Levine. 2002. Law and finance: Why does legal origin matter? Working Paper No. 9379, National Bureau of Economic Research.

Beck, Thorsten, and Ross Levine. 2004. Legal institutions and financial development. Working Paper No. 10417, National Bureau of Economic Research.

Bell, Clive, and Peter L. Rousseau. 2001. Post-independence India: A case of finance-led industrialization? Journal of Development Economics 65 (2): 153-75.

Bordo, Michael D., and Lars Jonung. 1987. The long-run behavior of the velocity of circulation. New York: Cambridge University Press.

Boyd, John H., Ross Levine and Bruce D. Smith. 2001. The impact of inflation on financial sector performance. Journal of Monetary Economics 47: 221-48. 
Bruno, Michael, and William Easterly. 1998. Inflation crises and long-run growth. Journal of Monetary Economics 41: 3-26.

Cameron, Rondo, with the collaboration of O. Crisp, Hugh T. Patrick, and Richard Tilly. 1967. Banking in the early stages of industrialization: A study in comparative economic history. New York: Oxford University Press.

Capie, Forrest H. 2001a. The monetary dimension in eighteenth century England. Working paper, to be published in Festschrift for Patrick O’Brien.

Capie, Forrest H. 2001b. The origins and development of stable fiscal and monetary institutions in England. In The Legacy of Western European Fiscal and Monetary Institutions for the New World, ed. Michael D. Bordo and Roberto Cortes Conde. Cambridge: Cambridge University Press.

Demetriades, Panicos O., and Khaled A. Hussein. 1996. Does financial development cause economic growth? Time-series evidence from 16 countries. Journal of Development Economics 51: 387411.

de Vries, Jan, and A. van der Woude. 1997. The first modern economy: Success, failure, and perseverence of the Dutch economy, 1500-1815. Cambridge: Cambridge University Press.

Eichengreen, Barry. 1992. Golden fetters: the gold standard and the Great Depression, 1919-1939. New York: Oxford University Press.

Flandreau, Marc, and Frederic Zumer. 2004. The making of global finance, 1800-1915. Paris: Organisation for Economic Cooperation and Development.

Franks, Julian R, Colin P. Mayer and Stefano Rossi. 2005. Ownership: evolution and regulation. ECGI Finance Working Paper No. 09/2003; EFA 2004 Maastricht Meetings Paper No. 3205; AFA 2003 Washington, DC Meetings. 
Friedman, Milton, and Anna J. Schwartz. 1982. Monetary trends in the United States and the United Kingdom. Chicago: University of Chicago Press.

Gerschenkron, Alexander. 1962. Economic backwardness in historical perspective, a book of essays. Cambridge, MA: Harvard University Press.

Goldsmith, Raymond W. 1969. Financial structure and development. New Haven: Yale University Press.

King, Robert G., and Ross Levine. 1993. Finance and growth: Schumpeter might be right. Quarterly Journal of Economics 108: 717-37 (a).

La Porta, Rafael, Florencio Lopez-de-Silanes, Andrei Shleifer, and Robert W. Vishny. 1997. Legal determinants of external finance. Journal of Finance 52(3), Papers and Proceedings: 1131-1150.

La Porta, Rafael, Florencio Lopez-de-Silanes, Andrei Shleifer, and Robert W. Vishny. 1998. Law and finance. Journal of Political Economy 106(6): 1113-1155.

Lamoreaux, Naomi R., and Jean-Laurent Rosenthal. 2004. Legal regime and business's organizational choice: a comparison of France and the United States. Working Paper No. 10288, National Bureau of Economic Research.

Leblang, David. 2003. To defend or to devalue: The political economy of exchange rate policy. International Studies Quarterly 47: 533-59.

Leblang, David. 2004. Is democracy incompatible with international economic stability? In The future of the international monetary system, ed. Marc Uzan. London: Edward Elgar Publishing.

Levine, Ross, Norman Loayza, and Thorsten Beck. 2000. Financial intermediation and growth: Causality and causes. Journal of Monetary Economics 46 (1): 31-77.

McKinnon, Ronald I. 1973. Money and capital in economic development. Washington, DC: Brookings Institution. 
North, Douglas, and Barry Weingast. 1989. Constitutions and commitment: evolution of institutions governing public choice in seventeenth-century England. Journal of Economic History 49.

Obstfeld, Maurice, and Alan M. Taylor. 2000. Global Capital Markets: Integration, Crises, and Growth. Japan-U.S. Center Sanwa Monographs on International Financial Markets. Cambridge: Cambridge University Press.

Pagan, Adrian. 1984. Econometric issues in the estimation of regressions with generated regressors. International Economic Review 25(1): 221-247.

Pagano, Marco, and Paolo Volpin. 2005. The political economy of corporate governance. American Economic Review 95 (4): 1005-30.

Perrotti, Enrico C., and Ernst-Ludwig Von Thaddon. 2005. The political economy of corporate control and labor rents. Journal of Political Economy, forthcoming.

Rousseau, Peter L. 1999. Finance, investment, and growth in Meiji-era Japan. Japan and the World Economy 11(2): 185-198.

Rousseau, Peter L. 2003. Historical perspectives on financial development and economic growth. Federal Reserve Bank of St. Louis Review 85(4): 81-105.

Rousseau, Peter L., and Richard Sylla. 2003. Financial systems, economic growth, and globalization. In Globalization in Historical Perspective, ed. Michael D. Bordo, Alan M. Taylor, and Jeffrey G. Williamson. Chicago: University of Chicago Press, pp. 373-413.

Rousseau, Peter L., and Richard Sylla. 2005. Emerging financial markets and early U.S. growth. Explorations in Economic History 42(1): 1-26.

Rousseau, Peter L., and Paul Wachtel. 1998. Financial intermediation and economic performance: Historical evidence from five industrialized countries. Journal of Money, Credit and Banking 30 (4): $657-78$. 
Rousseau, Peter L., and Paul Wachtel. 2000. Equity markets and growth: Cross country evidence on timing and outcomes. Journal of Banking and Finance 24 (12): 1933-57.

Rousseau, Peter L., and Paul Wachtel. 2002. Inflation thresholds and the finance-growth nexus. Journal of International Money and Finance 21 (6): 777-93.

Sylla, Richard. 1969. Federal policy, banking market structure, and capital mobilization in the United States, 1863-1913. Journal of Economic History 29(4): 657-686.

Sylla, Richard. 1998. U.S. securities markets and the banking system, 1790-1840. Federal Reserve Bank of St. Louis Review 80(3): 83-98.

Sylla, Richard. 2002. Financial systems and economic modernization. Journal of Economic History 62(2): 277-291.

World Bank, 1999. World Development Indicators. World Bank, Washington, DC. 